\title{
FURTHER STUDIES ON INCREASED SUSCEPTIBILITY TO CHLOROFORM POISONING PRODUCED IN THE ALBINO RAT BY INJECTION OF CRYSTALLINE THYROXIN
}

\author{
By MONROE A. McIVER ANd ELEANOR A. WINTER
}

(From the Surgical Service of the Mary Imogene Bassett Hospital, Cooperstown, N. Y.)

(Received for publication October 14, 1941)

In a previous article (1) evidence was presented of increased susceptibility to chloroform poisoning produced in the albino rat by injection of crystalline thyroxin. The present study was undertaken to obtain data that might throw light on the mechanism of this phenomenon, and was centered on two points. First: Is the increased susceptibility to chloroform poisoning in the hyperthyroid rat due to the fact that the glycogen content of the liver is diminished in the presence of hyperthyroidism? Second: Does a high protein diet afford the same protection against chloroform poisoning to the liver of a hyperthyroid rat that it does to the normal liver?

To test the hypothesis that a low glycogen content of the liver is responsible for the increased susceptibility to chloroform poisoning in rats following the administration of thyroxin, the problem was approached in two ways. In one set of experiments an attempt was made to maintain a normal glycogen content of the liver in animals receiving thyroxin, and their susceptibility to chloroform poisoning was then tested. In another series the liver glycogen was reduced by means other than administration of thyroxin, and the susceptibility to chloroform poisoning of this group was contrasted with that of animals whose liver glycogen had been reduced by administration of thyroxin.

\section{METHOD AND MATERIALS}

The experiments were carried out on male albino rats having an initial weight of between 150 grams and 175 grams.

The standard diet consisted of Purina Dog Chow (Ralston Purina Company). This was modified in some of the experiments by the addition of carbohydrate in the form of 6 grams of sucrose daily; and in others by the addition of 0.4 gram of Squibb's yeast or 3.0 grams of Fleischmann's dried irradiated yeast, number IF-39, daily (presented by the Fleischmann Laboratories). Each gram of Squibb's yeast contained 50 International units
$B_{1}, 15$ Sherman-Bourquin units $B_{2}, 90$ gamma $B_{6}, 35$ Jukes-Lepkovsky units Filtrate Factor, nicotinic acid. Each gram of Fleischmann's yeast contained 18 International units $B_{1}, 20$ Sherman-Bourquin units $B_{2}$.

In certain experiments a high protein diet was given, made up of Casein number 453 (Casein Company of America) 81.2 per cent, Crisco 7.2 per cent, McCollum salt mixture number 185 (2) 4.0 per cent, Vegex (Vitamin Food Company) 7.4 per cent, Squibb Navitol 0.3 per cent. (This is the high protein diet used by Goldschmidt et al. (3) and somewhat similar to that used by Moise and Smith (4).)

The thyroid hormone was given in the form of Squibb's crystalline thyroxin, 1 administered daily by subcutaneous injection over a period of approximately 2 weeks in doses of $0.1 \mathrm{mgm} .^{2}$

The chloroform was injected subcutaneously in doses of $0.8 \mathrm{cc}$. per $\mathrm{kgm}$. of rat, and was diluted with sterile mineral oil so that the total volume per dose was 0.5 cc.

Since we were interested only in the acute effect of chloroform poisoning, animals that survived were usually sacrificed at the end of 48 hours.

Animals that died were autopsied as soon as possible and blocks of tissue from their livers and other organs were fixed in Zenker's solution and in 4 per cent formalin. Animals that were sacrificed were killed by a sharp blow at the base of the skull and were autopsied in the same manner. Where glycogen determinations were to be carried out, the liver was removed at once-within $30 \mathrm{sec}$ onds. A portion of the liver was immediately fixed in absolute alcohol for later staining with Best's carmine. At the same time, duplicate portions of the liver weighing about 1 gram each were placed (for chemical determinations of the glycogen) in weighed tubes containing 30 per cent potassium hydroxide. The tubes were quickly heated in a water bath to initiate decomposition of the liver tissue, then removed for re-weighing, again returned to the water bath, and heated until the tissue had been completely dissolved. This process was followed by pre-

1 The crystalline thyroxin used in these experiments was kindly contributed by E. R. Squibb and Sons.

2 In the preliminary experiments $0.2 \mathrm{mgm}$. was given. With this dose a number of rats died; but since there was some respiratory infection among these rats, it was diffcult to evaluate the relative importance of the infection and the larger dose of thyroxin. In later experiments, using the $0.1 \mathrm{mgm}$. dose, the animals in general remained in good condition. 
cipitation of the glycogen with 95 per cent alcohol, according to the method of Good, Kramer and Somogyi (5). After hydrolysis, the glycogen was determined as glucose by a modification of the Hagedorn-Jensen technique (6).

\section{EXPERIMENTAL}

The animals were kept for a period of at least one week before experiments were begun in order to make sure they were all in healthy condition and to allow them to become adjusted to the laboratory environment. They were weighed every second day. In general their nutrition was well maintained. The control animals on standard diet uniformly gained in weight-usually 30 to 35 grams over the 2 -week period. The animals receiving thyroxin usually suffered a loss of weight, although in many instances they maintained their weight or even made some gain. The rats often had a slight diarrhoea after the first thyroxin injections but generally remained in good condition.

Preliminary experiments. That the administration of the thyroid hormone results in a low level of glycogen in the liver was clearly demonstrated by the experiments of Cramer and Krause (7) in

TABLE I

The effect of the administration of crystalline thyroxin on the level of liver glycogen

It will be noted that the liver glycogen of animals receiving crystalline thyroxin over a period of from 11 to 17 days varied from 1.5 to 0.18 gram per cent, while in the control animals the level was from 5.0 to 7.1 grams per cent.

\begin{tabular}{|c|c|c|c|c|c|c|c|}
\hline \multirow{2}{*}{$\begin{array}{c}\text { Rat } \\
\text { num- } \\
\text { ber }\end{array}$} & \multirow{2}{*}{$\begin{array}{l}\text { Initial } \\
\text { weight }\end{array}$} & \multicolumn{2}{|c|}{$\begin{array}{l}\text { Administration } \\
\text { of crystalline } \\
\text { thyroxin }\end{array}$} & \multirow{2}{*}{$\begin{array}{c}\text { Average } \\
\text { daily } \\
\text { food } \\
\text { intake. } \\
\text { Standard } \\
\text { diet }\end{array}$} & \multirow{2}{*}{$\underset{\text { meight }}{\text { Maxi- }}$} & \multirow{2}{*}{$\begin{array}{c}\text { Final } \\
\text { weight }\end{array}$} & \multirow{2}{*}{$\begin{array}{l}\text { Liver } \\
\text { gly- } \\
\text { cogen }\end{array}$} \\
\hline & & $\begin{array}{c}\text { Total } \\
\text { amount }\end{array}$ & $\begin{array}{c}\text { Dura- } \\
\text { tion }\end{array}$ & & & & \\
\hline & grams & mgm. & days & grams & grams & grams & $\begin{array}{l}\text { grams } \\
\text { per cent }\end{array}$ \\
\hline $\begin{array}{l}148 \\
153 \\
154 \\
157 \\
159 \\
167 \\
173 \\
185 \\
192 \\
201 \\
203\end{array}$ & $\begin{array}{l}203 \\
203 \\
207 \\
191 \\
181 \\
183 \\
131 \\
184 \\
191 \\
172 \\
191\end{array}$ & $\begin{array}{l}1.6 \\
1.6 \\
1.6 \\
1.5 \\
1.5 \\
1.5 \\
1.1 \\
1.7 \\
1.7 \\
1.7 \\
1.7\end{array}$ & $\begin{array}{l}11 \\
11 \\
11 \\
15 \\
15 \\
15 \\
11 \\
17 \\
17 \\
17 \\
17\end{array}$ & $\begin{array}{l}15 \\
15 \\
19 \\
14 \\
15 \\
11 \\
18 \\
13 \\
18 \\
16 \\
19\end{array}$ & $\begin{array}{l}243 \\
234 \\
242 \\
191 \\
183 \\
183 \\
173 \\
187 \\
191 \\
183 \\
191\end{array}$ & $\begin{array}{l}232 \\
233 \\
225 \\
175 \\
165 \\
151 \\
134 \\
177 \\
177 \\
183 \\
165\end{array}$ & $\begin{array}{l}0.31 \\
0.48 \\
0.75 \\
1.3 \\
0.45 \\
0.40 \\
0.76 \\
0.57 \\
0.70 \\
1.5 \\
0.18\end{array}$ \\
\hline $\begin{array}{l}144 \\
145 \\
149 \\
152\end{array}$ & $\begin{array}{l}193 \\
207 \\
218 \\
192\end{array}$ & \multicolumn{2}{|c|}{$\begin{array}{l}\text { Control } \\
\text { Control } \\
\text { Control } \\
\text { Control }\end{array}$} & $\begin{array}{l}17 \\
20 \\
18 \\
15\end{array}$ & $\begin{array}{l}219 \\
245 \\
243 \\
230\end{array}$ & $\begin{array}{l}219 \\
245 \\
243 \\
230\end{array}$ & $\begin{array}{l}6.9 \\
6.4 \\
7.1 \\
5.0\end{array}$ \\
\hline
\end{tabular}

1913, and confirmed by Kuriyama $(8,9)$ in 1917. More recently, Coggeshall and Greene (10) have shown that a hyperthyroid animal has difficulty in storing glycogen in the liver.

The present experiments (Table I) show that a level of glycogen from 7.1 to 5.0 grams per cent was maintained in the group of control animals on the standard diet; whereas the level in animals receiving injections of crystalline thyroxin was from 1.5 to 0.18 gram per cent.

Attempts to maintain a normal level of liver glycogen in animals receiving injections of crystalline thyroxin. Kuriyama (9) found that if he gave a sufficiently high caloric diet to his thyroidfed rats the liver glycogen was in some cases maintained to a limited extent. More recently, Drill (11) reported that rats receiving injections of crystalline thyroxin and large doses of yeast maintained a normal level of liver glycogen. Our own efforts along these lines were only partially successful. As shown in Table II, the addition to the diet of sucrose, either alone or combined with relatively small doses of yeast, did not appreciably alter the level of liver glycogen. When, however, large doses of yeast were added to the diet of rats Numbers 253,255, 256, 258, 261, and 263 (Table II), the level of liver glycogen in 4 out of 6 instances was appreciably higher than in the rats not receiving this treatment.

Administration of chloroform to a group of animals that had received large doses of yeast in addition to their regular diet. A group of animals (Table III) treated by the same methods as rats Numbers 253, 255, 256, 258, 261, and 263, described above, were injected at the end of 14 days with $0.8 \mathrm{cc}$. of chloroform per kgm. of rat. ${ }^{3}$ Presumably, on the basis of the data given above, the majority of these animals had a liver glycogen level of about 2.5 grams per cent. It will be noted that only 2 of these rats survived. Three additional rats (Table III) that had previously been on a normal diet were given intraperitoneal injections of 5 per cent glucose at the time of the chloroform injections in an effort to increase

8 It had been found in earlier studies (1) that animals receiving this and somewhat larger doses of chloroform survived for more than $\mathbf{4 8}$ hours if they had not received preliminary thyroxin injections. 
TABLE II

The effect on liver glycogen of additions of sucrose and varying amounts of yeast to the standard diet of hyperthyroid rats

It will be noted that the liver glycogen in rats that received sucrose, alone or combined with a small amount of yeast, was low; whereas the liver glycogen in 4 out of 6 rats that received a large amount of yeast was found to be at an appreciably higher level.

\begin{tabular}{|c|c|c|c|c|c|c|c|c|}
\hline \multirow{2}{*}{ Rat number } & \multirow{2}{*}{$\begin{array}{l}\text { Initial } \\
\text { weight }\end{array}$} & \multicolumn{2}{|c|}{$\begin{array}{l}\text { Administration of } \\
\text { crystalline thyroxin }\end{array}$} & \multicolumn{2}{|c|}{ Average daily food intake } & \multirow{2}{*}{$\underset{\text { weight }}{\text { Maximum }}$} & \multirow{2}{*}{$\underset{\text { weight }}{\text { Final }}$} & \multirow{2}{*}{$\begin{array}{c}\text { Liver } \\
\text { glycogen }\end{array}$} \\
\hline & & $\begin{array}{c}\text { Total } \\
\text { amount }\end{array}$ & Duration & $\begin{array}{c}\text { Standard } \\
\text { diet }\end{array}$ & Added sucrose or yeast & & & \\
\hline & grams & $m g m$. & days & grams & & grams & grams & $\underset{\text { per cent }}{\text { grams }}$ \\
\hline $\begin{array}{l}198 \\
199 \\
200 \\
202\end{array}$ & $\begin{array}{l}173 \\
160 \\
203 \\
185\end{array}$ & $\begin{array}{l}1.6 \\
1.6 \\
1.6 \\
1.6\end{array}$ & $\begin{array}{l}16 \\
16 \\
16 \\
16\end{array}$ & $\begin{array}{l}19 \\
15 \\
16 \\
16\end{array}$ & $\begin{array}{l}6 \text { grams sucrose } \\
6 \text { grams sucrose } \\
6 \text { grams sucrose } \\
6 \text { grams sucrose }\end{array}$ & $\begin{array}{l}173 \\
173 \\
203 \\
187\end{array}$ & $\begin{array}{l}167 \\
173 \\
189 \\
183\end{array}$ & $\begin{array}{l}0.10 \\
0.11 \\
0.17 \\
0.11\end{array}$ \\
\hline 183 & 187 & 1.6 & 16 & & 6 grams sucrose and & 193 & 193 & 0.16 \\
\hline 193 & 176 & 1.6 & 16 & 9 & 6 grams sucrose and & 181 & 179 & 0.42 \\
\hline 196 & 197 & 1.6 & 16 & 12 & $\begin{array}{l}6 \text { grams sucrose and } \\
0.4 \text { grams yeast }\end{array}$ & 197 & 187 & 0.11 \\
\hline 197 & 157 & 1.6 & 16 & 9 & $\begin{array}{l}6 \text { grams sucrose and } \\
0.4 \text { grams yeast }\end{array}$ & 173 & 168 & 0.12 \\
\hline $\begin{array}{l}165 \\
175 \\
182 \\
186 \\
189 \\
190\end{array}$ & $\begin{array}{l}192 \\
178 \\
179 \\
162 \\
189 \\
195\end{array}$ & $\begin{array}{l}1.2 \\
1.2 \\
1.7 \\
1.7 \\
1.7 \\
1.7\end{array}$ & $\begin{array}{l}13 \\
13 \\
17 \\
17 \\
17 \\
17\end{array}$ & $\begin{array}{l}19 \\
19 \\
16 \\
14 \\
15 \\
17\end{array}$ & $\begin{array}{l}0.4 \text { grams yeast } \\
0.4 \text { grams yeast } \\
0.4 \text { grams yeast } \\
0.4 \text { grams yeast } \\
0.4 \text { grams yeast } \\
0.4 \text { grams yeast }\end{array}$ & $\begin{array}{l}192 \\
178 \\
179 \\
174 \\
197 \\
197\end{array}$ & $\begin{array}{l}183 \\
169 \\
173 \\
171 \\
187 \\
194\end{array}$ & $\begin{array}{l}0.68 \\
0.83 \\
0.28 \\
1.1 \\
0.43 \\
0.49\end{array}$ \\
\hline $\begin{array}{l}253 \\
255 \\
256 \\
258 \\
261 \\
263\end{array}$ & $\begin{array}{l}179 \\
196 \\
182 \\
199 \\
173 \\
214\end{array}$ & $\begin{array}{l}1.2 \\
1.2 \\
1.2 \\
1.2 \\
1.2 \\
1.2\end{array}$ & $\begin{array}{l}12 \\
12 \\
12 \\
12 \\
12 \\
12\end{array}$ & $\begin{array}{l}13 \\
16 \\
14 \\
15 \\
14 \\
14\end{array}$ & $\begin{array}{l}3 \text { grams yeast } \\
3 \text { grams yeast } \\
3 \text { grams yeast } \\
3 \text { grams yeast } \\
3 \text { grams yeast } \\
3 \text { grams yeast }\end{array}$ & $\begin{array}{l}180 \\
196 \\
199 \\
199 \\
178 \\
214\end{array}$ & $\begin{array}{l}160 \\
185 \\
199 \\
181 \\
159 \\
189\end{array}$ & $\begin{array}{l}2.6 \\
0.83 \\
2.9 \\
2.6 \\
0.43 \\
1.7\end{array}$ \\
\hline
\end{tabular}

the amount of glycogen in the liver; none of these rats survived. ${ }^{4}$

Comment. Since we were not able, by any of the methods tried, to obtain a completely normal level of liver glycogen, the evidence cannot be taken as conclusive that the increased susceptibility to chloroform poisoning shown by hyperthyroid rats is not connected with the low glycogen content of the liver found in these animals. The problem was therefore approached from another point of view. It was reasoned that, if the depletion of the liver glycogen were wholly or largely responsible for the increased susceptibility to chloroform poisoning in hyperthyroid animals, the same dose of chloroform would be equally

4 It is interesting that Davis and Whipple (13) found that glucose given intravenously during chloroform anesthesia was of little benefit in protecting the liver against chloroform poisoning and may even have had a deleterious effect. fatal to animals depleted of liver glycogen by other means. Experiments to test this hypothesis were undertaken.

Effects of chloroform injections on rats depleted of liver glycogen by fasting. It has been shown by Cori and Cori (12), Coggeshall and Greene (10), and Goldschmidt et al. (3) that withholding food for 24 to 48 hours will reduce the liver glycogen to a low level. The present experiments confirmed this finding, showing that the liver glycogen is reduced to a comparable, or in certain instances even a lower level, by this period of fasting than by the administration of thyroxin ( $c f$. Tables IV and I).

To test the effects of chloroform injections on fasting rats as contrasted with hyperthyroid rats, 2 groups of animals were studied (Table V). One group, on the standard diet, received injections of crystalline thyroxin over a period of 12 to 16 days. The second group, also placed on the 
TABLE III

The effect of the administration of chloroform to 2 groups of rats treated with crystalline thyroxin

One group received 3.0 grams of yeast daily, in addition to the standard diet; the other group received intraperitoneal injections of glucose solution. It will be noted that in spite of these attempts to prevent depletion of the liver glycogen, only 2 of the 9 animals survived the chloroform injection.

\begin{tabular}{|c|c|c|c|c|c|c|c|c|c|}
\hline \multirow{2}{*}{$\begin{array}{c}\text { Rat } \\
\text { number }\end{array}$} & \multirow{2}{*}{$\begin{array}{l}\text { Initial } \\
\text { weight }\end{array}$} & \multicolumn{2}{|c|}{$\begin{array}{l}\text { Administration of } \\
\text { crystalline thyroxin }\end{array}$} & \multicolumn{2}{|c|}{$\begin{array}{l}\text { Average daily } \\
\text { food intake }\end{array}$} & \multirow{2}{*}{$\begin{array}{l}\text { Dose of } \\
\text { chloroform } \\
\text { per kilo } \\
\text { of body } \\
\text { weight }\end{array}$} & \multirow{2}{*}{$\underset{\text { weight }}{\text { Maximum }}$} & \multirow{2}{*}{$\begin{array}{c}\text { Final } \\
\text { weight }\end{array}$} & \multirow{2}{*}{ Results } \\
\hline & & $\begin{array}{c}\text { Total } \\
\text { amount }\end{array}$ & Duration & $\begin{array}{l}\text { Standard } \\
\text { diet }\end{array}$ & $\begin{array}{l}\text { Yeast } \\
\text { daily }\end{array}$ & & & & \\
\hline $\begin{array}{l}252 \\
257 \\
259 \\
260 \\
254 \\
262\end{array}$ & $\begin{array}{c}\text { grams } \\
181 \\
193 \\
164 \\
185 \\
189 \\
209\end{array}$ & $\begin{array}{c}m g m . \\
1.3 \\
1.3 \\
1.3 \\
1.3 \\
1.3 \\
1.3\end{array}$ & $\begin{array}{c}\text { days } \\
13 \\
13 \\
13 \\
13 \\
13 \\
13\end{array}$ & $\begin{array}{c}\text { grams } \\
14 \\
13 \\
13 \\
14 \\
15 \\
16\end{array}$ & $\begin{array}{c}\text { grams } \\
3 \\
3 \\
3 \\
3 \\
3 \\
3\end{array}$ & $\begin{array}{l}c c . \\
0.8 \\
0.8 \\
0.8 \\
0.8 \\
0.8 \\
0.8\end{array}$ & $\begin{array}{c}\text { grams } \\
181 \\
193 \\
184 \\
185 \\
190 \\
209\end{array}$ & $\begin{array}{c}\text { grams } \\
160 \\
181 \\
160 \\
171 \\
177 \\
200\end{array}$ & $\begin{array}{l}\text { Dead in } 24 \text { hours } \\
\text { Dead in } 24 \text { hours } \\
\text { Dead in } 24 \text { hours } \\
\text { Dead in } 28 \text { hours } \\
\text { Survived } \\
\text { Survived }\end{array}$ \\
\hline & & & & & $\begin{array}{c}\mathbf{5 \%} \\
\text { Glucose } \\
\text { cc. }\end{array}$ & & & & \\
\hline $\begin{array}{l}28 \\
41 \\
51\end{array}$ & $\begin{array}{l}201 \\
189 \\
175\end{array}$ & $\begin{array}{l}3.4 \\
4.3 \\
4.3\end{array}$ & $\begin{array}{l}21 \\
15 \\
15\end{array}$ & $\begin{array}{c}\text { Not } \\
\text { weighed }\end{array}$ & $\begin{array}{l}10^{*} \\
10 \dagger \\
10 \ddagger\end{array}$ & $\begin{array}{l}1.5 \\
0.8 \\
0.4\end{array}$ & $\begin{array}{l}233 \\
199 \\
175\end{array}$ & $\begin{array}{l}233 \\
195 \\
166\end{array}$ & $\begin{array}{l}\text { Dead in } 35 \text { hours } \\
\text { Dead in } 45 \text { hours } \\
\text { Dead in } 20 \text { hours }\end{array}$ \\
\hline
\end{tabular}

* One injection the day preceding administration of chloroform, 1 at the time of chloroform injection, and 1 the succeeding day.

† One injection the day preceding chloroform administration, 1 at the time of chloroform administration.

$\ddagger$ One injection at the time of chloroform administration.

standard diet at the same time, received no food during the last 24 to 55 hours (water was freely available). At the end of the period, the animals of both groups were injected with $0.8 \mathrm{cc}$. of chloroform per $\mathrm{kgm}$. of body weight. Among the 6 animals that had received preliminary treatment with thyroxin, there were 4 deaths; whereas among the 8 animals that had been deprived of food, there was only 1 death.

Comment. The question as to whether a high level of liver glycogen affords protection, either directly or indirectly, to the normal liver against chloroform poisoning, is still a moot point $(3,15)$.
The present experiments, however, show that depletion of liver glycogen by the administration of thyroxin is not the major factor in the increased susceptibility to chloroform poisoning shown by hyperthyroid rats.

Influence of a high protein diet. It has been reported by numerous investigators $(3,4,13,14)$ that a diet high in protein affords considerable protection to the normal liver from the injurious effects of chloroform. To ascertain whether or not this holds true in the presence of hyperthyroidism, a group of rats were placed on a diet containing approximately 81 per cent of protein

TABLE IV

The effect on liver glycogen of fasting for 24 to 48 hours

Contrast with Controls numbers 144, 145, 149 and 152, Table I; also with the group of animals receiving crystalline thyroxin, same Table.

\begin{tabular}{|c|c|c|c|c|c|}
\hline Rat number & $\begin{array}{r}\text { Initial } \\
\text { weight }\end{array}$ & Experimental treatment & $\begin{array}{l}\text { Weight at } \\
\text { beginning } \\
\text { of fast }\end{array}$ & $\begin{array}{c}\text { Final } \\
\text { weight }\end{array}$ & $\begin{array}{c}\text { Liver } \\
\text { glycogen }\end{array}$ \\
\hline $\begin{array}{l}135 \\
146 \\
151 \\
147 \\
155\end{array}$ & $\begin{array}{c}\text { grams } \\
175 \\
199 \\
196 \\
207 \\
190\end{array}$ & $\begin{array}{l}\text { Food withheld } 24 \text { hours; water given freely } \\
\text { Food withheld } 24 \text { hours; water given freely } \\
\text { Food withheld } 24 \text { hours; water given freely } \\
\text { Food withheld } 48 \text { hours; water given freely } \\
\text { Food withheld } 48 \text { hours; water given freely }\end{array}$ & $\begin{array}{c}\text { grams } \\
219 \\
232 \\
225 \\
242 \\
199\end{array}$ & $\begin{array}{c}\text { grams } \\
\\
207 \\
205 \\
199 \\
188\end{array}$ & $\begin{array}{c}\text { grams } \\
\text { per cent } \\
0.57 \\
0.24 \\
5.2 * \\
0.23 \\
0.26\end{array}$ \\
\hline
\end{tabular}

* We have no explanation to offer for the normal reading in Animal number 151. 
TABLE V

The effect of the injection of chloroform on animals that had received crystalline thyroxin in contrast with the effect on animals that had been deprived of food for 24 to 55 hours

It will be noted that 4 out of 6 of the thyroxin-injected animals died within 20 hours, while all but 1 of the animals from which food had been withheld survived.

\begin{tabular}{|c|c|c|c|c|c|c|c|c|}
\hline \multirow{2}{*}{ Rat number } & \multirow{2}{*}{$\begin{array}{l}\text { Initial } \\
\text { weight }\end{array}$} & \multicolumn{2}{|c|}{$\begin{array}{l}\text { Administration of } \\
\text { crystalline thyroxin }\end{array}$} & \multirow{2}{*}{$\begin{array}{c}\text { Average } \\
\text { daily food } \\
\text { intake. } \\
\text { Standard } \\
\text { diet }\end{array}$} & \multirow{2}{*}{$\begin{array}{l}\text { Dese of } \\
\text { chloroform } \\
\text { per bilo } \\
\text { of body } \\
\text { weight }\end{array}$} & \multirow{2}{*}{$\begin{array}{l}\text { Maximum } \\
\text { weight }\end{array}$} & \multirow{2}{*}{$\begin{array}{l}\text { Final } \\
\text { weight }\end{array}$} & \multirow{2}{*}{ Results } \\
\hline & & $\begin{array}{l}\text { Total } \\
\text { amount }\end{array}$ & Duration & & & & & \\
\hline $\begin{array}{l}139 \\
140 \\
158 \\
168 \\
172 \\
161\end{array}$ & $\begin{array}{l}\text { grams } \\
177 \\
164 \\
183 \\
185 \\
175 \\
186\end{array}$ & $\begin{array}{l}m g m . \\
1.6 \\
1.3 \\
1.6 \\
1.6 \\
1.5 \\
1.6\end{array}$ & $\begin{array}{l}\text { days } \\
13 \\
14 \\
16 \\
16 \\
16 \\
16\end{array}$ & $\begin{array}{l}\operatorname{srams} \\
10 \\
10 \\
13 \\
16 \\
14 \\
17\end{array}$ & $\begin{array}{l}\text { cc. } \\
0.8 \\
0.8 \\
0.8 \\
0.8 \\
0.8 \\
0.8\end{array}$ & $\begin{array}{l}\text { grame } \\
177 \\
179 \\
187 \\
185 \\
179 \\
186\end{array}$ & $\begin{array}{l}\text { grams } \\
163 \\
167 \\
187 \\
156 \\
165 \\
163\end{array}$ & $\begin{array}{l}\text { Dead in } 18 \text { hours } \\
\text { Survived } \\
\text { Dead in } 15 \text { hours } \\
\text { Dead in } 15 \text { hours } \\
\text { Dead in } 20 \text { hours } \\
\text { Survived }\end{array}$ \\
\hline & \multicolumn{3}{|c|}{ Food withheld } & & & $\begin{array}{l}\text { Weight at } \\
\text { beginning } \\
\text { of fast }\end{array}$ & & \multirow[b]{2}{*}{$\begin{array}{l}\text { Survived } \\
\text { Survived } \\
\text { Survived } \\
\text { Survived } \\
\text { Dead in } 17 \text { hours* } \\
\text { Survived } \\
\text { Survived } \\
\text { Survived }\end{array}$} \\
\hline $\begin{array}{l}136 \\
137 \\
142 \\
143 \\
156 \\
164 \\
166 \\
169\end{array}$ & $\begin{array}{l}161 \\
152 \\
153 \\
150 \\
170 \\
164 \\
163 \\
165\end{array}$ & \multicolumn{2}{|c|}{$\begin{array}{c}\text { hours } \\
24 \\
24 \\
24 \\
48 \\
48 \\
55 \\
55 \\
55\end{array}$} & $\begin{array}{l}10 \\
11 \\
12 \\
11 \\
12 \\
11 \\
13 \\
12\end{array}$ & $\begin{array}{l}0.8 \\
0.8 \\
0.8 \\
0.8 \\
0.8 \\
0.8 \\
0.8 \\
0.8\end{array}$ & $\begin{array}{c}\text { erams } \\
181 \\
189 \\
181 \\
191 \\
181 \\
170 \\
214 \\
209\end{array}$ & $\begin{array}{l}170 \\
173 \\
162 \\
179 \\
145 \\
125 \\
180 \\
172\end{array}$ & \\
\hline
\end{tabular}

* Had not eaten well for several days preceding fast.

for a period of 2 weeks, during which time they groups received an injection of $0.8 \mathrm{cc}$. of chlororeceived daily injections of crystalline thyroxin. form per $\mathrm{kgm}$. of rat. The results are shown in A control group of 6 rats received the same diet Table VI. It will be noted that all the animals but no thyroxin. At the end of 15 days both that had received thyroxin plus a high protein

TABLE VI

The effect of chloroform injections on 2 groups of animals fed on a high protein diet

It will be noted that this diet did not afford protection against chloroform poisoning to animals receiving crystalline thyroxin.

\begin{tabular}{|c|c|c|c|c|c|c|c|c|}
\hline \multirow{2}{*}{ Rat number } & \multirow{2}{*}{$\begin{array}{l}\text { Initial } \\
\text { weight }\end{array}$} & \multicolumn{2}{|c|}{$\begin{array}{l}\text { Administration of } \\
\text { crystalline thyroxin }\end{array}$} & \multirow{2}{*}{$\begin{array}{c}\text { Average } \\
\text { daily food } \\
\text { intake. } \\
\text { Casein } \\
\text { diet }\end{array}$} & \multirow{2}{*}{$\begin{array}{c}\text { Dose of } \\
\text { chloroform } \\
\text { per kilo } \\
\text { of body } \\
\text { weight }\end{array}$} & \multirow{2}{*}{$\underset{\text { weight }}{\text { Maximum }}$} & \multirow{2}{*}{$\begin{array}{l}\text { Final } \\
\text { weight }\end{array}$} & \multirow{2}{*}{ Results } \\
\hline & & $\begin{array}{c}\text { Total } \\
\text { amount }\end{array}$ & Duration & & & & & \\
\hline $\begin{array}{l}240 \\
241 \\
242 \\
243 \\
244 \\
245\end{array}$ & $\begin{array}{c}\text { grams } \\
215 \\
199 \\
190 \\
209 \\
209 \\
199\end{array}$ & $\begin{array}{c}\text { mgm. } \\
1.5 \\
1.5 \\
1.5 \\
1.5 \\
1.5 \\
1.5\end{array}$ & $\begin{array}{l}\text { days } \\
15 \\
15 \\
15 \\
15 \\
15 \\
15\end{array}$ & $\begin{array}{c}\text { srams } \\
14 \\
10 \\
11 \\
11 \\
16 \\
11\end{array}$ & $\begin{array}{l}c c . \\
0.8 \\
0.8 \\
0.8 \\
0.8 \\
0.8 \\
0.8\end{array}$ & $\begin{array}{c}\text { grams } \\
215 \\
200 \\
195 \\
211 \\
209 \\
207\end{array}$ & $\begin{array}{c}\text { grams } \\
175 \\
175 \\
165 \\
170 \\
179 \\
161\end{array}$ & $\begin{array}{l}\text { Dead in } 18 \text { hours* } \\
\text { Dead in } 42 \text { hours* } \\
\text { Dead in } 24 \text { hours* } \\
\text { Dead in } 21 \text { hours* } \\
\text { Dead in } 21 \text { hours* } \\
\text { Dead in } 20 \text { hours* }\end{array}$ \\
\hline $\begin{array}{l}230 \\
231 \\
232 \\
236 \\
238 \\
250\end{array}$ & $\begin{array}{l}226 \\
259 \\
276 \\
259 \\
221 \\
226\end{array}$ & \multicolumn{2}{|c|}{$\begin{array}{l}\text { Control } \\
\text { Control } \\
\text { Control } \\
\text { Control } \\
\text { Control } \\
\text { Control }\end{array}$} & $\begin{array}{r}12 \\
19 \\
12 \\
8 \\
12 \\
15\end{array}$ & $\begin{array}{l}0.8 \\
0.8 \\
0.8 \\
0.8 \\
0.8 \\
0.8\end{array}$ & $\begin{array}{l}226 \\
259 \\
278 \\
259 \\
221 \\
226\end{array}$ & $\begin{array}{l}224 \\
235 \\
278 \\
236 \\
217 \\
201\end{array}$ & $\begin{array}{l}\text { Survived } 48 \text { hours } \\
\text { Survived } 48 \text { hours } \\
\text { Survived } 48 \text { hours } \\
\text { Survived } 48 \text { hours } \\
\text { Survived } 48 \text { hours } \\
\text { Survived } 48 \text { hours } †\end{array}$ \\
\hline
\end{tabular}

* Showed histological evidence of extensive liver damage.

$\dagger$ Moribund at 48 hours. 
diet died within 42 hours, all but 1 dying within 24 hours ; ${ }^{5}$ whereas the animals that did not receive thyroxin all survived 48 hours, at which time they were sacrificed.

Comment. The exact mechanism by which a high protein diet affords protection to the normal liver against chloroform poisoning is still a matter of some conjecture. Whatever the correct interpretation, it is of some interest that this protection is not afforded in the presence of hyperthyroidism.

Histological studies. The changes found at autopsy in the liver and other organs of the animals that had received thyroxin followed by chloroform injections have been described in a previous report (1). In the present studies, similar changes were found in animals that were autopsied, the liver lesions consisting in varying degrees of central necrosis, often extreme. In considering the effects of chloroform, it should be borne in mind that Goodpasture (16) found, in experiments on rabbits which had been receiving thyroid hormone, that when small doses of chloroform were given by inhalation, the principal pathological changes occurred in the myocardium; whereas when the chloroform was injected subcutaneously, the greatest effect was upon the liver.

\section{CONCLUSIONS}

1. Our data do not furnish support of the view that the increased susceptibility to chloroform poisoning in the hyperthyroid rat is due chiefly to the low level of liver glycogen found in these animals.

2. A high protein diet does not afford protection against chloroform poisoning to the liver of animals receiving thyroid hormone.

\section{BIBLIOGRAPHY}

1. McIver, M. A., Increased susceptibility to chloroform poisoning produced in the albino rat by injection of crystalline thyroxin. Proc. Soc. Exper. Biol. and Med., 1940, 45, 201.

5 The substitution of a small amount of a mixture of dextrose and maltose (Karo Corn Syrup) for a part of the Casein and Crisco in the high protein diet seems to increase somewhat the resistance of hyperthyroid rats to chloroform poisoning; but our experiments on this point were too few in number to be taken as conclusive.
2. McCollum, E. V., and Simonds, N., A biological analysis of pellagra-producing diets. II. The minimum requirements of the two unidentified dietary factors for maintenance as contrasted with growth. J. Biol. Chem., 1917, 32, 181.

3. Goldschmidt, S., Vars, H. M., and Ravdin, I. S., The influence of the foodstuffs upon the susceptibility of the liver to injury by chloroform and the probable mechanism of their action. J. Clin. Invest., 1939, 18, 277.

4. Moise, T. S., and Smith, A. H., Diet and tissue growth. I. The regeneration of liver tissue on various adequate diets. J. Exper. Med., 1924, 40, 13.

5. Good, C. A., Kramer, H., and Somogyi, M., The determination of glycogen. J. Biol. Chem., 1933, $100,485$.

6. Peters, J., P., and Van Slyke, D. D., Quantitative Clinical Chemistry. Vol. II. Williams and Wilkins, Baltimore, 1932, p. 471.

7. Cramer, W., and Krause, R. A., Carbohydrate metabolism and its relation to the thyroid gland. Proc. Roy. Soc. London, s.B., 1913, 86, 550.

8. Kuriyama, S., The influence of thyroid feeding upon carbohydrate metabolism. Am. J. Physiol., 1917, 43, 481.

9. Kuriyama, S., The influence of thyroid feeding upon carbohydrate metabolism. I. The storage and mobilization of the liver glycogen in thyroid-fed animals. J. Biol. Chem., 1918, 33, 193.

10. Coggeshall, H. C., and Greene, J. A., The influence of desiccated thyroid gland, thyroxin, and inorganic iodine upon the storage of glycogen in the liver of the albino rat under controlled conditions. Am. J. Physiol., 1933, 105, 103.

11. Drill, V. A., The effect of yeast on the liver glycogen of white rats during hyperthyroidism. J. Nutrition, 1937, 14, 355.

12. Cori, C. F., and Cori, G. T., The fate of sugar in the animal body. II. The relation between sugar oxidation and glycogen formation in normal and insulinized rats during the absorption of glucose. J. Biol. Chem., 1926, 70, 557.

13. Davis, N. C., and Whipple, G. H., The influence of fasting and various diets on the liver injury effected by chloroform anesthesia. Paper I. Arch. Int. Med., 1919, 23, 612.

14. Miller, L. L., and Whipple, G. H., Chloroform liver injury increases as protein stores decrease. Studies in nitrogen metabolism in these dogs. Am. J. M. Sc., 1940, 199, 204.

15. Davis, N. C., and Whipple, G. H., The influence of drugs and chemical agents on the liver necrosis of chloroform anesthesia. Paper II. Arch. Int. Med., 1919, 23, 636.

16. Goodpasture, E. W., The influence of thyroid products on the production of myocardial necrosis. J. Exper. Med., 1921, 34, 407. 